Retraction

\title{
Retraction: IL-6 Promotes Cancer Stemness and Oncogenicity in U2OS and MG-63 Osteosarcoma Cells by Upregulating the OPN-STAT3 Pathway
}

Journal of Cancer

CIvyspring International Publisher. This is an open access article distributed under the terms of the Creative Commons Attribution License (https://creativecommons.org/licenses/by/4.0/). See http://ivyspring.com/terms for full terms and conditions.

Published: 2021.10.08

Corrected article: J Cancer 2019; 10(26):6511-6525. doi:10.7150/jca.29931.

This article (IL-6 Promotes Cancer Stemness and Oncogenicity in U2OS and MG-63 Osteosarcoma Cells by Upregulating the OPN-STAT3 Pathway. Chuan Zhang, Kun Ma, Wu-Yin Li. J Cancer 2019; 10(26):6511-6525) has been retracted due to concerns on multiple image duplications as identified by PubPeer users. The corresponding author has been contacted by the journal, and the authors expressed apology for their negligence and mistakes in this paper. 